\title{
EFEKTIVITAS FUNGSI KELOMPOK TANI DALAM MENINGKATKAN PENDAPATAN PETANI PADI DI DESA HANDAPHERANG KECAMATAN CIJEUNGJING KABUPATEN CIAMIS
}

\author{
THE EFFECTIVENESS OF THE FUNCTION OF FARMER GROUPS IN \\ INCREASING THE INCOME OF PADDY FARMERS OF HANDAPHERANG \\ VILLAGE CIJEUNGJING DISTRICT CIAMIS REGENCY
}

\author{
IFAN NUR SOPYAN ${ }^{1 *}$, IWAN SETIAWAN ${ }^{2}$, MUHAMAD NURDIN YUSUF ${ }^{1}$ \\ ${ }^{1}$ Fakultas Pertanian Universitas Galuh \\ ${ }^{2}$ Fakultas Pertanian Universitas Padjadjaran \\ *E-mail : ifannurs53@gmail.com
}

\begin{abstract}
ABSTRAK
Kelemahan struktural petani adalah sempitnya rata-rata penguasaan lahan, hal tersebut dapat diantisipasi dengan dibentuknya kelompok tani yang dijadikan sebagai sarana untuk meningkatkan produksi pada akhirnya akan meningkatkan pendapatan petani. Penelitian ini bertujuan untuk mengetahui: 1) Pendapatan petani padi di Desa Handapherang Kecamatan Cijeungjing Kabupaten Ciamis dan 2) Efektivitas fungsi kelompok tani dalam meningkatkan pendapatan petani padi di Desa Handapherang Kecamatan Cijeungjing Kabupaten Ciamis. Penelitian ini menggunakan metode survei yang dianalisis secara deskriptif kuantitatif. Sampel pada penelitian ini ditentukan secara acak sederhana berdasarkan Rumus Slovin pada tingkat kesalahan 10\%. Tujuan penelitian pertama dan kedua dianalisis secara deskriptif menggunakan rumus pendapatan dan sistem skoring untuk menentukan efektivitas kelompok tani. Hasil penelitian menunjukkan bahwa: 1) Besarnya pendapatan petani padi per hektar di Desa Handapherang Kecamatan Cijeungjing Kabupaten Ciamis adalah Rp $11.422 .385,22$; 2) Efektivitas fungsi kelompok tani dalam meningkatkan pendapatan petani padi di Desa Handapherang Kecamatan Cijeungjing berada dalam kategori rendah dikarenakan belum tercapainya fungsi kelompok tani dalam mencapai produksi yang diharapkan sehingga kelompok tani belum mampu memberikan pengaruh yang besar terhadap pendapatan petani.
\end{abstract}

Kata kunci: efektivitas kelompok tani, pendapatan, usahatani padi

\begin{abstract}
The structural weakness of farmers is the narrow average land holdings. This can be anticipated by the formation of farmer groups which are used as a means to increase production, which in turn will increase farmer's income. The study is aimed to determine: 1) The income of paddy farmers in Handapherang Village, Cijeungjing District, Ciamis Regency and 2) The effectiveness of the function of farmer groups in increasing the income of paddy farmers in Handapherang Village, Cijeungjing District, Ciamis Regency. This study uses a survey method that is analyzed descriptively quantitative. The sample in this study was determined randomly based on the Slovin formula at an error rate of 10\%. The first and second research objectives were analyzed descriptively using an income formula and a scoring system to determine the effectiveness of farmer groups. The results shows that: 1) The amount of paddy farmers' income per hectare in Handapherang Village, Cijeungjing District, Ciamis Regency was Rp. 11,422,385.22; 2) The effectiveness of the function of farmer groups in increasing the income of paddy farmers in Handapherang Village, Cijeungjing Subdistrict, is in the low category because the function of the farmer groups in achieving the expected production has not been achieved so that the farmer groups have not been able to have a big influence on farmers' income.
\end{abstract}

Key words: farmer group effectiveness, income, paddy farming 


\section{PENDAHULUAN}

Sebagian besar penduduk Indonesia bermata pencaharian di sektor pertanian. Kemajuan sektor pertanian dapat dilihat sampai sejauh mana kemajuan pembangunan pertanian yang merupakan suatu proses yang di tunjukkan untuk memperbesar produksi pertanian sekaligus mempertinggi pendapatan produktivitas usaha petani. Peningkatan produktivitas usahatani memerlukan pengelolaan yang efisien sehingga diperlukan adanya perubahan perilaku untuk mampu bertani dengan baik dan berusaha tani yang lebih menguntungkan (Hayanti, 2019).

Pada tahun 2007 pemerintah menargetkan produksi beras nasional harus meningkat setiap tahunnya, namun laju produktivitas padi sawah secara nasional dalam beberapa tahun terakhir mengalami penurunan. Bahkan di beberapa daerah produktivitasnya cenderung menurun (Sumarno 1997; Suwono, dkk 1999). Hal tersebut dikarenakan berkurangnya lahan sawah yang berpindah fungsi menjadi pemukiman penduduk.

Permasalahan yang dihadapi, mendorong petani untuk membentuk suatu kelompok tani untuk kerjasama. Seiring berjalannya waktu, maka berbagai macam polemik yang terjadi di desa menjadi alasan bagi petani untuk berkolaborasi dan bermusyawarah untuk mendapatkan solusi demi kemajuan bersama dalam upaya meningkatkan produksi pertanian secara luas. Peningkatan produktivitas tersebut pada akhirnya akan meningkatkan pendapatan petani dan taraf hidup.

Jumlah kelompok tani di Kabupaten Ciamis adalah 2.774 kelompok tani yang tersebar di beberapa kecamatan. Adanya kelembagaan petani akan berperan penting dalam memajukan petani jika meningkatkan pendapatan. Menurut Dinas Pertanian dan Ketahanan Pangan Kabupaten Ciamis (2020) dari 27 Kecamatan di Kabupaten Ciamis, Kecamatan Cijeungjing merupakan kecamatan yang memiliki 81 kelompok tani yang tersebar di beberapa desa dan memiliki keaktifan kelompok tani, administrasi, kemudahan memperoleh sarana produksi bagi anggota kelompok dan keterbukaan antara anggota dengan pengurus maupun masyarakat umum.

Desa Handapherang merupakan mempunyai 7 kelompok tani yang aktif dan kontinyu dalam melakukan usahataninya dengan jumlah anggota 569 orang. Kelompok tani yang terdapat di Desa Handapherang terbentuk berdasarkan keinginan dan harapan yang besar untuk meningkatkan pendapatan dan taraf hidup 
masyarakat petani di pedesaan. Adapun tujuan dari penelitian ini adalah untuk mengetahui: (1) Besarnya pendapatan usahatani padi di Desa Handapherang Kecamatan Cijeungjing Kabupaten Ciamis? (2) Efektivitas fungsi kelompok tani di Desa Handapherang Kecamatan Cijeungjing Kabupaten Ciamis?

\section{METODE PENELITIAN}

Jenis penelitian ini adalah penelitian deskriptif kuantitatif. Menurut (Arikunto, 2007) penelitian deskriptif kuantitatif yaitu penelitian yang bertujuan untuk menguraikan atau menggambarkan tentang sifat-sifat (karakteristik) dari suatu keadaan atau objek penelitian. Pendekatan penelitian yang digunakan dalam penelitian ini adalah metode survei. Data dikumpulkan melalui wawancara dan pengisian angket.

Data dalam penelitian ini menggunakan data primer dan sekunder. Data primer adalah data asli yang dikumpulkan sendiri oleh peneliti untuk menjawab masalah penelitiannya secara khusus diperoleh melalui hasil kuesioner dan wawancara yang dilakukan kepada responden langsung. Sedangkan data sekunder yaitu data yang telah dikumpulkan pihak lain, bukan oleh peneliti sendiri diperoleh dari instansi terkait dan cara studi literatur yaitu dengan mempelajari buku- buku, dokumen-dokumen, dan hasil-hasil penelitian yang berhubungan dengan masalah-masalah yang teliti.

Penelitian ini dilakukan di Desa Handapherang Kecamatan Cijeungjing Kabupaten Ciamis ditentukan secara sengaja (purposive) dengan pertimbangan bahwa Desa Handpaherang memiliki kelompok tani yang aktif dibandingkan dengan desa lain di Kecamatan Cijeungjing. Responden dalam penelitian sebanyak 85 petani yang tergabung dalam kelompok tani di Desa Handapherang Kecamatan Cijeungjing Kabupaten Ciamis yang diambil secara acak dari anggota pupolasi sebanyak 569 orang dengan menggunakan Rumus Slovin.

Teknik analisis data yang digunakan dalam penelitian ini adalah untuk mengetahui efektivitas fungsi kelompok tani dilakukan secara deskriptif kualitatif yang dipertajam dengan pendekatan Likert menggunakan sistem skoring (Vredenbergt, 1988 dalam Sundari et al., 2012). Dalam bahasan ini respon petani dikategorikan dengan memberi tiga kategori yaitu rendah, sedang, dan tinggi. Sedangkan untuk mengetahui pendapatan petani dapat dilakukan dengan menggunakan rumusan sebagai berikut:

a. Biaya total 
Menurut Firdaus (2008), biaya total merupakan keseluruhan jumlah biaya produksi yang dikeluarkan. Biaya total dapat dirumuskan sebagai berikut:

$$
\mathrm{TC}=\mathrm{TFC}+\mathrm{TVC}
$$

Keterangan :

TC $($ Total Cost $)=$ Biaya total

TFC $($ Total Fixed Cost $)=$ Biaya tetap

TVC $($ Total Variable Cost $)=$ Biaya tidak tetap/variabel

b. Penerimaan

Penerimaan usahatani adalah perkalian antara volume produksi yang diperoleh dengan harga jual, dapat dihitung dengan rumus (Soekartawi, 2006) sebagai berikut:

$$
\mathrm{TR}=\mathrm{Q} \times \mathrm{P}
$$

Keterangan :

TR $($ Total Revenue $)=$ Penerimaan usaha

$\mathrm{Q}($ Quantity $)=$ Produk yang dihasilkan

$\mathrm{P}($ Price $)=$ Harga jual produk yang dihasilkan

c. Pendapatan

Pendapatan usahatani dapat diketahui dengan menghitung selisih antara penerimaan dan pengeluaran serta dapat dihitung dengan menggunakan rumus (Soekartawi, 1995) sebagai berikut:

$$
\mathrm{Pd}=\mathrm{TR}-\mathrm{TC}
$$

Keterangan :

$\mathrm{Pd}=$ pendapatan usahatani
$\mathrm{TR}=$ penerimaan total (Total Revenue)

$\mathrm{TC}=$ biaya total $($ Total Cost $)$

\section{HASIL DAN PEMBAHASAN}

\section{Identitas Responden}

Jumlah responden dalam penelitian ini adalah sebayak 85 petani yang tergabung ke dalam kelompok tani..

\section{Umur Responden}

Semakin produktif umur petani memungkinkan mereka untuk berusahatani secara lebih optimal dikarenakan kemampuan fisik petani yang lebih mumpuni dibandingkan dengan petani yang lebih tua. Umur responden petani di Desa Handapherang sebagian besar berusia antara 48 - 58 tahun, dengan demikian hampir seluruh responden termasuk usia yang produktif.

\section{Pendidikan Responden}

Pendidikan merupakan salah satu faktor yang dapat menentukan tinggi rendahnya sumber daya manusia. Semakin tinggi tingkat pendidikan seseorang semakin tinggi pula respon terhadap teknologi baru dan cara berpikir. Tingkat pendidikan responden petani di Desa Handapherang sebagian besar hanya menjalani pendidikan dasar (SD dan SMP). Dengan keterbatasannya tingkat pendidikan ini dapat berpengaruh pada peningkatan pendapat petani. 
Tanggungan Keluarga Responden

Jumlah tanggungan keluarga yang dimaksud dalam penelitian ini adalah jumlah anggota keluarga yang menjadi tanggungan responden untuk memenuhi kebutuhan hidupnya.Tanggungan keluarga responden petani semuanya mempunyai tanggungan keluarga 1-3 orang. Dengan demikian semakin banyaknya tanggungan keluarga, maka petani harus mampu meningkatkan pendapat untuk memenuhi kebutuhan hidup keluarganya.

\section{Luas Lahan Responden}

Sebagian besar responden memiliki luas lahan yang sempit yaitu sebanyak 80 orang. Sempitnya lahan menyebabkan return dari usahatani menjadi rendah, sehingga sangat berpengaruh pada pendapatan petani.

\section{Pengalaman Berusahatani Responden}

Pengalaman yang dimiliki seseorang pada ummumnya akan mempengaruhi proses pengambilan keputusan. Hasil penelitian menunjukkan bahwa sebagian besar responden sebanyak 68 orang mempunyai pengalaman bertani antara 1020 tahun.

\section{Analisis Biaya Total, Penerimaan dan Pendapatan}

\section{Biaya Total}

Biaya total merupakan keseluruhan jumlah biaya produksi yang dikeluarkan. Biaya yang dikeluarkan oleh responden kelompok tani padi per hektar per satu kali proses produksi di Desa Handapherang Kecamatan Cijeungjing sebesar Rp 489.539,56,- biaya tetap dan biaya variabel Rp 8.211.637,17,sehingga rata-rata biaya total $\mathrm{Rp}$ $8.701 .176,73,-\quad$ dari semua biaya dikeluarkan.

\section{Penerimaan Usahatani Padi}

Hasil produksi padi yang dihasilkan dalam satu kali proses produksi per hektar di daerah penelitian adalah 4.471,90 $\mathrm{kg}$ sedangkan harga yang berlaku di daerah penelitian adalah $4.500 / \mathrm{kg}$. Jadi penerimaan usahatani per hektar pe satu kali proses produksi sebesar Rp 20.123.561,95,--

\section{Pendapatan Usahatani Padi}

Pendapatan responden dapat diketahui dengan mengurangi penerimaan dengan total biaya yang dikeluarkan per hektar per musim tanam. Diketahui sebelumnya penerimaan Rp 20.123.561,95,- Sedangkan biaya total yang dikeluarkan petani sebesar Rp 8.701.176,73,-. Sehingga pendapatan kelompok tani per hektar per satu kali proses produksi sebesar Rp 11.422.385,22,-.

\section{Efektivitas Kelompok Tani}

\section{Produktivitas Kelompok Tani}

(1) Sejauh mana tujuan kelompok tercapai dalam hal: 
a) Peningkatan produksi padi sawah dalam satu musim tanam terakhir

Hasil penelitian menunjukkan bahwa produksi padi di Desa Handapherang dalam musim tanam terakhir termasuk kategori sedang. Hal ini menunjukkan bahwa produksi padi yang dihasilkan petani stabil dikarenakan tidak adanya peningkatan produksi dalam satu musim tanam terakhir.

b) Peningkatan kepuasan anggota terhadap produksi padi sawahnya dalam musim tanam terakhir

Berdasarkan hasil penelitian kepuasan anggota kelompok tani di Desa Handapherang terhadap produksi padi dalam kategori tinggi. Dikarenakan mereka menyatakan puas dengan hasil produksinya dalam musim tanam terakhir.

(2) Jumlah rata-rata hasil produksi padi sawah yang dihasilkan oleh anggota dalam satu musim tanam terakhir

Dari hasil penelitian menunjukkan bahwa sebagian besar rata-rata produksi yang dihasilkan oleh anggota kelompok tani dalam kategori rendah, dikarenakan produksi yang dihasilkan 1 kali musim panen $<3$ ton/ha. Hal tersebut disebabkan sebagian besar petani di Desa Handapherang memiliki lahan yang sempit.

(3) Kesesuaian tujuan kelompok dengan tujuan anggota
Berdasarkan hasil penelitian dapat diketahui bahwa tujuan anggota kelompok tani di Desa Handapherang dalam kategori tinggi. Hal ini menunjukkan bahwa tujuan anggota sudah sesuai dengan tujuan kelompok tani yaitu meningkatkan produktivitas, menyediakan sarana produksi anggotanya dan menjalin hubungan harmonis antara anggota kelompok tani, serta tercapainya kepuasan anggota kelompok tani.

\section{Kepuasaan Anggota Kelompok Tani}

(1) Kepuasan anggota terhadap perannya dalam kelompok tani

Hasil penelitian menunjukkan bahwa kepuasan anggota terhadap perannya dalam kelompok tani termasuk kategori sedang. Hal ini menunjukkan bahwa petani yang tergabung dalam kelompok tani merasa cukup puas, karena merasa cukup berperan dalam kelompoknya.

(2) Kepuasaan anggota terhadap kemajuan kelompok tani

Berdasarkan penelitian menunjukkan bahwa kepuasan anggota terhadap kemajuan kelompok tani dalam kategori tinggi. Hal ini menunjukkan bahwa petani yang tergabung ke dalam kelompok tani merasa puas dengan kemajuan kelompok taninya. Dikarenakan adanya hubungan yang harmonis antara anggota kelompok tani. 
(3) Kepuasaan anggota terhadap kebebasan berpartisipasi dalam hal:

a) Perencanaan kegiatan kelompok tani

Dari hasil penelitian dapat diketahui bahwa kepuasan anggota terhadap perencanaan kegiatan kelompok tani dalam kategori sedang. Hal ini menunjukkan bahwa anggota kelompok tani merasa cukup puas, karena mereka kadang-kadang dilibatkan dalam perencanaan kegiatan kelompok taninya.

b) Pelaksaan kegiatan kelompok tani

Berdasarkan hasil penelitian dapat diketahui bahwa kepuasan anggota terhadap pelaksanaan kegiatan kelompok tani dalam kategori tinggi. Hal ini menunjukkan bahwa petani yang tergabung dalam kelompok tani merasa puas, karena mereka selalu dilibatkan dalam pelaksaan kegiatan kelompok tani.

c) Pencapaian hasil yang dicapai dalam setiap kegiatan

Hasil penelitian menunjukkan bahwa pencapaian hasil yang dicapai anggota

Efektivitas Fungsi Kelompok Tani Dalam Meningkatkan Pendapatan Petani Padi di Desa Handapherang Kecamatan Cijeungjing

dalam setiap kegiatan kelompok tani berada pada kategori sedang. Hal ini menunjukkan bahwa anggota kelompok tani kadangkadang berhasil dalam setiap kegiatan kelompoknya.

Dengan demikian produktivitas kelompok tani dalam kategori sedang serta kepuasan anggota kelompok tani dalam kategori tinggi. Untuk lebih jelasnya tingkat efektivitas kelompok tani dapat dilihat pada Tabel.

\begin{tabular}{cccccc}
\hline & & \multicolumn{3}{c}{ Pendapatan } & \multirow{2}{*}{ Total } \\
\cline { 3 - 5 } & & Rendah & Sedang & Tinggi & \\
\cline { 3 - 5 } Efektivitas Kelompok & Sedang & 38 & 16 & 1 & 55 \\
Tani & & $44.7 \%$ & $18.8 \%$ & $1.2 \%$ & $64.7 \%$ \\
& Tinggi & 13 & 13 & 4 & 30 \\
\cline { 3 - 5 } Total & & $15.3 \%$ & $15.3 \%$ & $4.7 \%$ & $35.3 \%$ \\
& & 51 & 29 & 5 & 85 \\
& & $60.0 \%$ & $34.1 \%$ & $5.9 \%$ & $100.0 \%$
\end{tabular}

Dari Tabel di atas dapat diketahui bahwa efektivitas fungsi kelompok tani dalam meningkatkan pendapatan petani di Desa Handapherang sebesar (60,0 \%)

dalam kategori rendah. Hal tersebut dikarenakan sebanyak 51 orang petani yang tergabung dalam kelompok tani tidak terjadi adanya peningkatan produksi padi 
yang disebabkan luas lahan sempit, belum maksimalnya peran petani dalam kelompoknya disebabkan mereka jarang dilibatkan dalam perencanaan dan pelaksanaan kegiatan sehingga hanya sebagian anggota kelompok tani yang berhasil mencapai produksi dalam satu kali musim panen terakhir.

Dengan demikian efektivitas fungsi kelompok tani dalam meningkatkan pendapatan petani memiliki penilaian rendah disebabkan belum tercapainya fungsi kelompok tani dalam mencapai produksi yang diharapkan dapat meningkatkan pendapatan petani setelah menjadi anggota dalam kelompok tani.

Hasil penelitian tersebut tidak sesuai dengan yang di kemukakan menurut Fidalia (2018) kelompok tani yang efektif maka pendapatan petani akan meningkat karena tercapainya fungsi kelompok tani dalam mencapai produksi, sehingga dengan meningkatnya produksi maka pendapatan petani juga akan meningkat.

Sedangkan menurut pendapat Ikbal (2014) menunjukan bahwa pendapatan usahatani padi sawah rata-rata mengalami peningkatan setelah petani tergabung dalam kelompok tani. .

Artinya kelompok tani yang berada di Desa Handapherang Kecamatan Cijeungjing Kabupaten Ciamis belum memberikan pengaruh yang besar terhadap pendapatan petani karena sebagian besar petani menyatakan tidak ada peningkatan pendapatan setelah petani bergabung dalam kelompok tani.

\section{KESIMPULAN DAN SARAN}

\section{Kesimpulan}

Berdasarkan hasil penelitian dan pembahasan maka dapat disimpulkan bahwa:

1) Pendapatan kelompok tani padi di Desa Handapherang Kecamatan Cijeungjing ialah sebesar Rp 11.422.385,22,- per hektar per satu kali proses produksi.

2) Efektivitas fungsi kelompok tani padi di Desa Handapherang Kecamatan Cijeungjing belum efektif karena dilihat dari produktifitas kelompok tani dalam kategori sedang sedangkan kepuasan anggota kelompok tani dalam kategori tinggi.

\section{Saran}

1) Supaya produktivitas padi meningkat sebaiknya penyuluh BPP beserta kelompok tani di Desa Handapherang lebih berkoordinasi lagi mengenai teknis pelaksanaan dalam peningkatan pendapatan.

2) Pemerintah instansi terkait hendaknya meningkatkan peran penyuluh dalam 
memberikan pendidikan non formal melalui kegiatan penyuluhan, pelatihan, dan pengawasan terhadap kegiatan yang telah dilakukan.

3) Untuk peneliti selanjutnya sebaiknya melakukan penelitian ini lebih lanjut mengenai Efektivitas Fungsi Kelompok Tani Dalam Meningkatkan Pendapatan Petani Padi di Desa Handapherang Kecamatan Cijeungjing Kabupaten Ciamis sehingga dapat membandingkan dengan penelitian ini, untuk lebih mengetahui apakah adanya perubahan dalam verifikasi data atau dalam pelaksanaanya.

\section{DAFTAR PUSTAKA}

Arikunto, S, (2007). Prosedur Penelitian : Suatu Pendekatan Praktik, Jakarta ; Rineka Cipta.

Atriyani, H. 2006. Efektivitas Kelompok Petani Nelayan Kecil (KPK) pada Program Peningkatan Pendapatan Petani Nelayan Kecil (P4K) di Kabupaten Tanggamus. Skripsi. Universitas Lampung.

Chaplin, J P. (2005). Kamus Lengkap Psikologi. Jakarta : Rajawali Pres.

Departemen Pertanian. 2007. Peraturan Menteri Pertanian Nomor: 273/Kpts/OT.160/4/2007 Tentang Pedoman Pembinaan Kelembagaan Tani. Lampiran 1 Pedoman
Penumbuhan dan Pengembangan Kelompok Tani dan Gabungan Kelompok Tani www. Deptan. go. id/bbd/admin/permentan, download 23 September 2018

Fidalia, L. 2018. Efektivitas Kelompoktani Dalam Meningkatkan Pendapatan Usahatani Cabai Merah (Capsicum annuum L) Dan Jagung (zee mass) Di Desa Margototo Kecamatan Metro Kibang Kabupaten Lampung Timur. Skripsi. Universitas Lampung.

Firdaus, M.2008. Manajemen Agribisnis. Jakarta: Bumi Aksara.

Hayanti, E., Afrianto, E. dan Isyaturriyadhah. 2019. Analisis Efektivitas Kelompok Tani di Desa Pulau Tengah Kecamatan Jangkat Kabupaten Merangin, Jambi, Indonesia. Jurnal Agri Sains Vol, 3 No.02.

Sartono, 2004. Manajemen Keuangan, Soal dan Penyelesaiannya. BPFE, Yogyakarta.

Soekartawi, 2006. Analisis Usahatani. Jakarta. Universitas Indonesia. 1995. Analisis Usahatani. Universitas Indonesia (UI-Press). Jakarta.

Sumarno, 1997. Agroteknologi sebagai Dasar Pembangunan Sistem Usahatani Pertanian Berkelajutan

Sundari, dkk. 2012. Laporan Akhir Kajian Efektivitas Metode Penyuluhan Dalam Percepatan Adopsi Inovasi Teknologi Pertanian. Balai Besar Pengkajian dan Pengembangan Teknologi Pertanian. Bogor. 